\title{
Potential of Diethyl Ether Clove (Syzygium aromaticum) Extract against Different Pathogens and in Combination with Antibiotic against MDR- resistant Staphylococcus aureus
}

\author{
Mona M. Abou El-Nour ${ }^{(1) \#}$, Mehreshan T. El-Mokadem ${ }^{(1)}$, Zeinat K. Mohammad ${ }^{(2)}$ \\ and Ghada S.M. Abdel-Wahab ${ }^{(3)}$ \\ ${ }^{(1)}$ Botany Department, Faculty of Science (Women's College), Ain Shams University, \\ ${ }^{(2)}$ Botany \& Microbiology Department, Faculty of Science, Cairo University and \\ ${ }^{(3)}$ National Organizations of Drug Control and Research, Cairo, Egypt.
}

\begin{abstract}
$\mathbf{I}$ N VITRO antimicrobial activity of different Syzygium aromaticum (clove) extracts was evaluated against 11 microbial strains sensitive to antibiotics. The antimicrobial activity was further evaluated against four clinical bacterial isolates resistant to antibiotics. The broad spectrum of activity was recorded for the diethyl ether extract comparative to other tested solvents. The clove extract was screened for its MIC against the tested strains, the MIC varied between 0.05 and $500 \mu \mathrm{g} / \mathrm{ml}$. The MIC of each clove extract and ciprofloxacin against the MDRStaphylococcus aureus were also evaluated and found to be 1024 and $256 \mu \mathrm{g} / \mathrm{ml}$, respectively. The interaction between clove extract and ciprofloxacin was described in terms of fractional inhibitory concentration (FIC) indices with the resistant Staphylococcus aureus a synergistic effect was verified from this combination. Separation of phytochemicals of diethyl ether clove extract indicating the presence of three different compounds. The antimicrobial activity of each separated compound was detected against the sensitive strain Staphylococcus aureus and compared with the microbial activity of the entire crude extract which gave better activity compared to the separated fractions. Clove extract was characterized by GC/MS, eugenol $(59.7 \%)$ and eugenol acetate $(34.5 \%)$ were recorded as major constituents. The anti-cancer potentiality of clove extract was assessed with different concentrations against breast (MCF-7) and colon (HCT-116) cancer cell lines. Growth inhibition percentage for colon cancer reached its maximum value $(86.4 \%$ ) at $125 \mu \mathrm{g} / \mathrm{ml}$, while, for breast cancer, it was $84.2 \%$ at $50 \mu \mathrm{g} / \mathrm{ml}$. The $\mathrm{IC}_{50}$ for breast and colon cancer were 26.5 and $27 \mu \mathrm{g} / \mathrm{ml}$, respectively.
\end{abstract}

Keywords: Syzygium aromaticum, Phytochemicals, Eugenol, Eugenol acetate, Anticancer.

\section{Introduction}

Throughout the last decades, the utilization of traditional medicine (TM) has extended worldwide and is gaining popularity, TM supplies information and represents a reservoir of pharmacologically active substances of medicines (Louw et al., 2002) proved that TM in developing countries uses broad variety of natural products in the treatment of popular infections. Different bacterial strains gained multidrug resistance to most of the existing first-line treatment drugs in several parts of the world (Shanahan et al., 2000). Therefore, this resistance moved the view of medical science to more efficient classes of antibiotics of natural origin. Plants have provided not only directly utilizable drugs, but also various compounds that can be used as starting steps for the synthesis of new drugs with better pharmacological properties (Mukherjee \& Wahile, 2006). Therefore the necessity to develop new drugs requires varied strategies, among them, the bio prospection of secondary metabolites produced by medicinal plants (Dionisi et al., 2012 and Shanmugam \& Bhavani, 2014). Bassam et al. (2004) tested the antimicrobial activity of 6 medicinal plant extracts in vitro, against four bacterial species Methicillin-resistant Staphylococcus aureus

\#Corresponding author email: monamn2003@yahoo.com

DOI: 10.21608/ejm.2018.2765.1043

C2018 National Information and Documentation Centre (NIDOC) 
and Bacillus subtilis were the most inhibited microorganisms. Syzygium aromaticum extract was the most active against multidrug resistant Pseudomonas aeruginosa and Escherichia coli. Ethanolic extract of four medicinal plants were subjected to in vitro antibacterial evaluation against few human pathogenic strains by Joshi et al. (2011) they found that Syzygium aromaticum was the most effective against Salmonella typhi. Khalid et al. (2016) showed that the Syzygium aromaticum (clove) flower bud extract has antibacterial activity against two bacterial isolates Bacillus and Serratia marcescens. In addition Oulkheir et al. (2017) found that clove essential oil produced an inhibition zone against $E$. coli of $16 \mathrm{~mm}$ and higher inhibitory zone $(20 \mathrm{~mm})$ against Salmonella ssp, while no antibacterial effect on $K$. pneumoniae. Meanwhile, there is a pressing need to create new antibacterial substances or new compounds that prevent resistance mechanisms and develop treatment to destroy multidrugresistant bacteria. In this respect, Torella et al. (2010) reported that remediation with antibacterial combinations, using different antibacterial agents is one of the most significant strategies to overcome multidrug-resistant organisms. Mohammad \& AlKayali (2016) demonstrated that the mixture of ampicillin, cefotaxime and amikacin in addition to plant extracts has synergistic effects on the studied $S$. aureus strains, and that the interaction between plant extracts was preferable for resistant strains than sensitive strains. Atteiaa \& Husseinb (2014) noticed good synergism between ethanolic extract from Syzygium aromaticum with different antibiotics comparing with water extract against $S$. aureus isolate. It may be suggested from results by Ghaly et al. (2015) that both clove extract and ciprofloxacin have efficacy against bacteria isolated from Clarias gariepinus in both in vivo and in vitro laboratory experiment. Chaieb et al. (2007) analyzed the chemical structure of the essential oil of Syzygium aromaticum, it was found that the main components of clove oil were eugenol $(88.6 \%)$, eugenol acetate $(5.6 \%)$, b-caryophyllene (1.4\%) and 2-heptanone $(0.9 \%)$ and that eugenol and eugenol acetate known to possess antibacterial and antifungal properties. Kumar et al. (2010) and Eyambe et al. (2011) proved that the antimicrobial characteristics of the clove are due to the presence of eugenol, an aromatic phenolic compound. In accordance Ababutain (2011) proved that clove extract strongly inhibited growth of $B$. subtilis, $P$. aeruginosa and $C$. albican, this due to that clove extract have eugenol compound which cause membrane disruption of bacteria. Cancer is the second main cause of death and is becoming the major one in old age. It has been expected that by 2030 the quantity of new cancer cases will increase by $70 \%$ worldwide due to demographic changes alone (Hoffman-Censits \& Fu, 2013). Natural and some synthetic compounds can inhibit, suppress, or reverse the progression of cancer. Natural products have confirmed to be the most efficient in terms of their ability to change the function of proteins related to cancer (Muhtasib, 2006). Plants, herbs, and spices used in folk and traditional medication have been accepted at present as one of the main sources of cancer chemo preventive drug. Epidemiological investigations suggested that antioxidant supplements might decrease the danger of breast cancer or breast cancer-related death (Fleischauer et al., 2003). Han \& Parker (2017) has been shown that clove essential oil (CEO) and its main active constituent eugenol, have antimicrobial, antifungal, antiviral, antioxidant, anti-inflammatory and anticancer properties and that CEO affected cell cycle control and cancer biology. This was largely consistent with previous findings of Kouidhi et al. (2010) and Kumar et al. (2014) who confirmed that CEO and eugenol appear to possess anticancer properties against breast, colorectal, lung and leukaemia cancer cells. Therefore the objective of this investigation was to study the antimicrobial performance of different clove extracts and the possibility to be used as successful antimicrobial agents against gram positive and negative bacteria as well as pathogenic fungi. Also separation and identification of the phytochemical composition of the extract to study the antimicrobial impacts of these separated compounds in their individual capacity compared to the entire extract against the sensitive strain $S$. aureus. The extract was further evaluated in combination with synthetic drug against MDR-bacteria. The effect against two types of cancer colon cell lines was also assessed.

\section{Material And Methods}

\section{Preparation of plant material and extracts}

The plant sample (clove buds) were air dried and subjected to dryness in oven at $45^{\circ} \mathrm{C}$, kept away from moisture in well-closed glass containers until extraction, the buds were grounded just before examination. Extracts of the grounded buds were prepared according to Deshpande et al. (2004) in which ten grams of each crushed air dried plant materials were soaked in $100 \mathrm{ml}$ water or organic solvent, mixed well and left for $48 \mathrm{~h}$., filtered by 
paper Watmann No. 1. Filtrate was concentrated using rotary vacuum evaporator apparatus at 90 $100^{\circ} \mathrm{C}$ (for water extraction) and $40-60^{\circ} \mathrm{C}$ (for solvents extraction) to constant volume $(10 \mathrm{ml})$. Extracts were stored in dark glass bottle at $4^{\circ} \mathrm{C}$ till using in the antimicrobial assays. In addition dried crude powder of Syzygium aromaticum buds were prepared according to Jonathan \& Fasidi (2003). The filtrate was concentrated until a dried crude powder (semisolid product) was obtained and stored in dark glass bottle at $4^{\circ} \mathrm{C}$ till use.

\section{Solvents}

Seven organic solvents of different polarities (ethanol, methanol, acetone, chloroform, benzene, petroleum ether and diethyl ether) were used for the extraction of the active components from the investigated plant. Cold distilled water was also used for extraction.

\section{Pathogenic strains tested for antimicrobial activity}

Extracts were individually tested for their antimicrobial activity against a panel of sensitive pathogenic strains, including bacteria (Staphylococcus aureus, Micrococcus luteus, Bacillus cereus, Klebsiella pneumonia, Escherichia coli, Pseudomonas aeruginosa and Salmonella. All strains are American Type Culture Collection (ATCC) (Table 1). Furthermore, clove extract was also tested for its antimicrobial activity against four antibiotic resistant pathogenic strains (Staphylococcus aureus, Escherichia coli, Salmonella typhi and Klebsiella pneumonia) isolated from hospitalized patients. Antibiotic sensitivity test was confirmed by the standard disc diffusion method (CLSI, 2005) against 10 antibiotics namely, Imipenem, Ampicillin, Gentamicin, Amikacin, Ciprofloxacin, Cefotaxime, Cefuroxime, Norfloxacin, Amoxiclav and Tazocin. Isolates were classified as sensitive, intermediate and resistant according to the National Committee for Clinical Laboratory Standards (NCCLS, 2002).

\section{Media used}

The different media were prepared according to Atlas (1993). Nutrient broth was used for preparing the starter inocula of the studied bacterial strains. Nutrient agar was used for the maintenance and antimicrobial activity assays of bacterial strains. Sabouraud dextrose broth medium was used for preparing yeast and fungi starter inocula and Sabouraud dextrose agar was used for the maintenance and antimicrobial assays of yeasts and fungi.
TABLE 1. ATCC code of the tested organisms.

\begin{tabular}{lc}
\hline Strains & ATCC \\
\hline Staphylococcus aureus & 25923 \\
Micrococcus luteus & 10240 \\
Bacillus cereus & 8236 \\
Klebsiella pneumoniae & 10031 \\
Escherichia coli & 25922 \\
Pseudomonas aeruginosa & 27853 \\
Salmonella typhi & 6539 \\
Candida albicans & 10231 \\
Saccharomyses cerevisiae & 9763 \\
Aspergillus niger & 1015 \\
Aspergillus flavus & 9296 \\
\hline
\end{tabular}

In vitro antimicrobial activity of clove extracts

The antimicrobial activity of all clove extracts was determined against all investigated strains (sensitive and resistant) by agar well-diffusion method according to the National Committee for Clinical Laboratory Standard (NCCLS, 1994). Control holes were filled with distilled water and/ or the tested solvents.

\section{Determination of minimum inhibition concentration (MIC)}

The MIC was evaluated for crude diethyl ether clove extract (most efficient solvent) against the tested sensitive strains, using agar dilution method according to EUCAST (2000) concentrations ranging from $0.05 \mu \mathrm{g} / \mathrm{ml}$ to $5000 \mu \mathrm{g} / \mathrm{ml}$ were studied. MIC was also evaluated for the crude clove extract as well as antibiotic (ciprofloxacin) against the multi-drug resistant Staphylococcus aureus. The extract and ciprofloxacin were serially diluted $(4-2028 \mu \mathrm{g} / \mathrm{ml})$ and the MIC values were determined for both agents. The negative control performed with dimethyl sulfoxide (DMSO) in the preparation of solutions presented no effects on bacterial growth.

\section{Antimicrobial efficiency of combined antibiotic and clove extract}

The interaction of compounds to create more profound microbial action, may be an important factor, the antimicrobial activity of antibiotic ciprofloxacin and plant extract combination was done by agar dilution checkerboard assay as described by Vidaillac et al. (2007). Concentrations ranging from 4 to $2048 \mu \mathrm{g} / \mathrm{ml}$ were investigated; the combined effect is analyzed by 
using measurements of the MIC of the individual components to calculate the FIC index (Mandal et al., 2004)

$$
\begin{array}{r}
\text { FIC }_{\text {antibiotic }}=\frac{\text { MIC of antibiotic in combinatio }}{\text { MIC of antibiotic alone }} \\
\text { FIC }_{\text {extract }}=\frac{\text { MIC of extract in combination }}{\text { MIC of extract alone }} \\
\text { FIC index }=\text { FIC }_{\text {antibiotic }+} \text { FIC } \text { extract }^{\text {int }}
\end{array}
$$

The interaction was classified as synergistic if the FIC index was less than or equal to 0.5 , partial synergy if the FIC index was greater than or equal to 0.5 and less than or equal 1.0 and antagonistic if the FIC index was greater than or equal to 1.0 (Gail et al., 1995).

\section{Separation of antimicrobial compounds of clove} extract

Diethyl ether clove extract was fractionated by using thin layer chromatography technique (TLC). $100 \mathrm{ml}$ of the solvent system (Toluene: ethyl acetate, $95: 5 \mathrm{v} / \mathrm{v}$ ) was poured in jar for $2 \mathrm{~h}$ to allow the saturation of the jar atmosphere with the solvent system (El-Deeb, 1985). The diluted clove diethyl ether extract $(10 \mathrm{mg} / \mathrm{ml})$ was spotted at $2 \mathrm{~cm}$ apart from the lower edge of the plates. Plates were inserted into the developing chamber and kept until solvent was ascended for about $15 \mathrm{~cm}$. The plate was removed and allowed to dry (Truiti \& Sarragiotto, 1998). TLC plates were run in duplicate for using in two purposes:

First: one set was visualized by spraying with vanillin- $\mathrm{H}_{3} \mathrm{PO}_{4}$ reagent for calculating the retention factor $(\mathrm{Rf})$ values of the separated components.

Second: the other set was visualized under UV transilluminator $(365 \mathrm{~nm})$ and the spots were marked to study the followings

\section{Antimicrobial activity of the separated phytochemicals}

The main separated bands were scraped and extracted with $2 \mathrm{ml}$ diethyl ether, centrifuged, and then the liquid layer was evaporated to dryness. The residue was dissolved in DMSO and tested for its inhibitory activity against sensitive Staphylococcus aureus by well diffusion method.

Infrared spectra (IR)

Infrared absorption spectrum of the main three separated compounds was estimated by Nicolet 6700, Transform infrared spectroscopy (TIR) spectrometer using the liquid cell at the National Research Institute, Giza, Egypt.

Gas chromatography-mass spectroscopy analyses of the tested extract

Gas chromatography/mass spectroscopy $(\mathrm{GC} /$ MS) was utilized to detect the chemical profiling present in crude clove extract. The chemical structure of each constituent was identified by comparing the mass spectra for their peaks with those of mass spectra computer library.

\section{Cytotoxicity test}

The sensitivity of two human cell line cancers (colon, HCT 116 tumor and breast MCF 7 tumor) to crude clove extract was tested by the SRB assay (Skehan et al., 1990) doxorubicin was used as positive control. The $\mathrm{IC}_{50}$ (Dose of the extracts which inhibits survival to $50 \%$ ) for the extract and control were calculated by using Graph-Pad Prism program (Graph-Pad, UK) (Houghton et al., 2007). Growth inhibition \% in presence of clove extract was calculated according to Sundaram et al. (2011).

\section{Statistical analysis}

All the experimental results were performed in triplicate and the data were statistically analyzed using Analysis of Variance (ANOVA) and Least Significant Difference (LSD) method to find out significant relationship at $\mathrm{P}<0.05$ according to Snedecor \& Cochran (1982).

\section{Results}

All the examined solvents provided positive results with varied inhibitory activity against all strains of the tested organisms, except water which recorded negative result (Fig. 1).

Comparatively, according to inhibition zone diameters, the diethyl ether demonstrated the maximum inhibitory effect compared to the other solvents, suggesting the presence of high level of active constituents in this extract. Antimicrobial drug-resistant strains are everywhere even in environment naive to human invasion, therefore antimicrobial potentiality of diethyl ether clove extract was studied against four clinical multidrug resistant isolates which were checked for their antibiotics sensitivity. Results indicated that clove extract have the potential to control the growth of all isolated resistant pathogens (Table 2). 


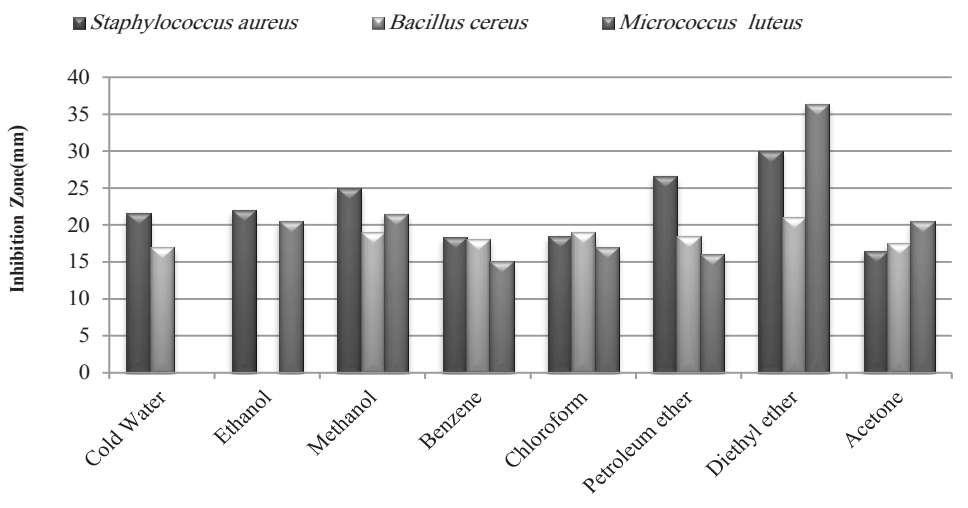

A

Solvents type
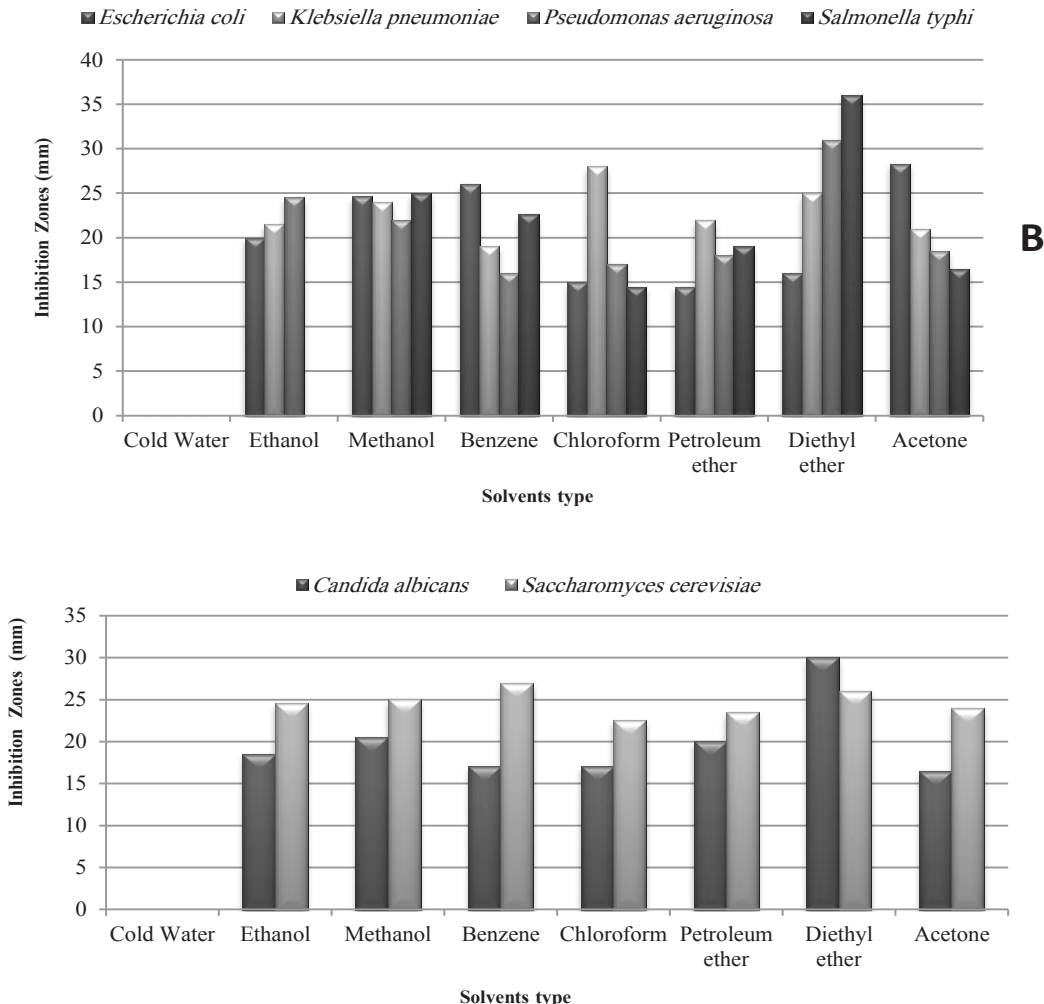

C

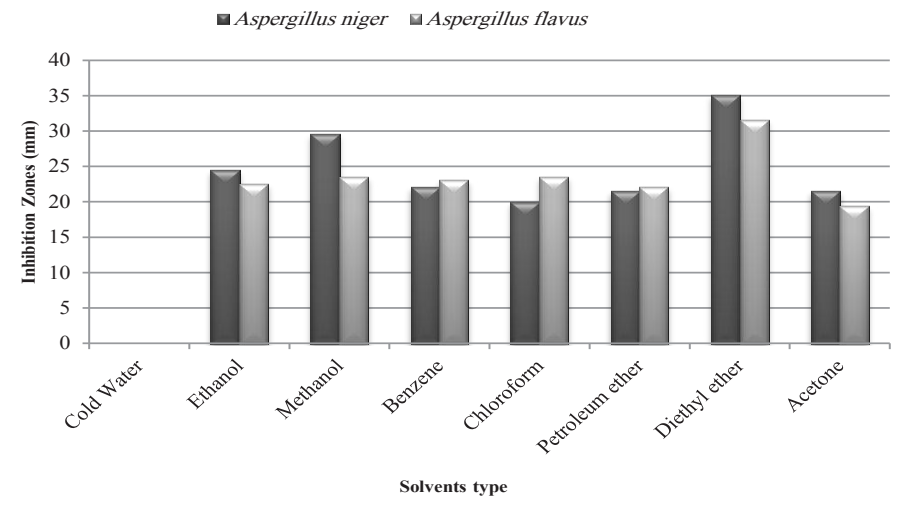

D

Fig. 1. Effect of Syzygium aromaticum extracts on (A) Gram +ve bacteria, (B) Gram -ve bacteria, (C) Yeasts and (D) Fungi . 
TABLE 2. Antimicrobial activity diethyl ether clove extract against MDR isolates.

\begin{tabular}{lc}
\hline Resistant isolates & $\begin{array}{c}\text { Inhibition } \\
\text { zones diameter } \\
(\mathbf{m m})\end{array}$ \\
\hline Staphylococcus aureus & 27.60 \\
Escherichia coli & 21.60 \\
Salmonella typhi & 27.30 \\
Klebsiella pneumoniae & 25.60 \\
\hline
\end{tabular}

Significant antimicrobial effects, expressed as MIC of crude extract, were observed against the studied sensitive strains, results recorded in Table 3 show great variation in MIC values ranging from 0.05 to $500 \mu \mathrm{g} / \mathrm{ml}$. Good correlation was found between the low inhibition zone recorded of the studied extract against $E$. coli (the most resistant) and the high MIC value $(500 \mu \mathrm{g} / \mathrm{ml})$. A strong activity of clove diethyl ether extract was noticed against $M$. luteus and Salmonella typhi as well as A. niger.

TABLE 3. MICs and inhibition activity of clove diethyl ether extract of the tested strains.

\begin{tabular}{lcc}
\hline Test organisms & $\begin{array}{c}\text { MIC } \\
\mathbf{M g} / \mathbf{m l}\end{array}$ & $\begin{array}{c}\text { Inhibition } \\
\text { zone diameter } \\
\text { (mm) }\end{array}$ \\
\hline Staphylococcus aureus & 0.50 & 30.00 \\
Bacillus cereus & 50.00 & 21.00 \\
Micrococcus luteus & 0.05 & 36.00 \\
Escherichia coli & 500.00 & 16.00 \\
Klebsiella pneumonia & 5.00 & 25.00 \\
Pseudomonas & 0.50 & 31.00 \\
aeruginosa & & 36.00 \\
Salmonella typhi & 0.05 & 30.00 \\
Candida albicans & 0.50 & 26.00 \\
Saccharomyces & 5.00 & 35.00 \\
cerevisiae & & 32.00 \\
Aspergillus niger & 0.05 & \\
Aspergillus flavus & 0.50 & \\
\hline
\end{tabular}

Since Staphylococcus aureus is an example of microorganisms that gained resistance to antibiotics mainly against ciprofloxacin (the recommended drug for $S$. aureus infection) so, it is of interest to evaluate the MIC values of each of clove extract and ciprofloxacin against the resistant $S$. aureus, Table 4 demonstrate the MICs values of each agent.
TABLE 4. MIC of clove extract and ciprofloxacin against resistant Staphylococcus aureus.

\begin{tabular}{lcc}
\hline \multirow{2}{*}{$\begin{array}{l}\text { Concentrations } \\
\boldsymbol{\mu g} / \mathbf{m l}\end{array}$} & \multicolumn{2}{c}{ Bacterial growth } \\
\cline { 2 - 3 } & Clove extract & Ciprofloxacin \\
\hline 4 & $\mathrm{ve}+$ & $+\mathrm{ve}$ \\
8 & $+\mathrm{ve}$ & $+\mathrm{ve}$ \\
16 & $+\mathrm{ve}$ & $+\mathrm{ve}$ \\
32 & $+\mathrm{ve}$ & $+\mathrm{ve}$ \\
64 & $+\mathrm{ve}$ & $+\mathrm{ve}$ \\
128 & $+\mathrm{ve}$ & $+\mathrm{ve}$ \\
256 & $+\mathrm{ve}$ & $-\mathrm{ve}$ \\
512 & $+\mathrm{ve}$ & $-\mathrm{ve}$ \\
1024 & $-\mathrm{ve}$ & $-\mathrm{ve}$ \\
2048 & $-\mathrm{ve}$ & $-\mathrm{ve}$ \\
\hline
\end{tabular}

Herbal drugs alternatively can be used in combination with synthetic drugs with enhanced activity against bacterial infections. Accordingly, the clove extract was combined with antibiotic ciprofloxacin in order to assess their efficiency against the resistant $S$. aureus. Combinations can lead to additive, synergistic or antagonistic effects, results in Table 5 demonstrate a marked reduction in the MIC of clove extract (from $1024 \mu \mathrm{g} / \mathrm{ml}$ to $16 \mu \mathrm{g} / \mathrm{ml}$ ) and the antibiotic ciprofloxacin (from $256 \mu \mathrm{g} / \mathrm{ml}$ to $64 \mu \mathrm{g} / \mathrm{ml}$ ) when combined together. The interactions were classified as additive if the effect is equal to the individual effects and antagonistic if the effect is less potent than the individuals. Synergism results from components of one factor aiding to the other, improving the total efficiency. The checkerboard plate assay is used to test the activities of several drugs in combination against bacteria by determining the fractional inhibition concentration (FICs) of all combinations tested. FIC Index results are explained as synergistic if FIC index $<0.5$, accordingly; the obtained value of FIC index $(0.265)$ illustrated a synergistic effect of the paired combination against the resistant $S$. aureus.

The Thin layer chromatogram of clove diethyl ether extract using thin layer chromatography and infrared spectra methodology indicated the presence of three active antimicrobial components (Photo 1) with three different color spots A, B and $\mathrm{C}$ and different $\mathrm{Rf}$ values (Table 6).

The separated compounds as well as the entire 
crude extract were examined for their antibacterial activity against the sensitive strain $S$. aureus. The inhibition zone diameters demonstrated that the

TABLE 5. Antimicrobial activity of clove extract and ciprofloxacin combination on resistant strain Staphylococcus aureus.

\begin{tabular}{|c|c|c|c|c|c|c|c|c|c|c|c|}
\hline & & \multicolumn{10}{|c|}{ Ciprofloxacin serial dilutions $(\mu \mathrm{g} / \mathrm{ml})$} \\
\hline \multirow{5}{*}{ 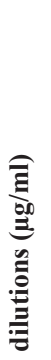 } & & 4 & 8 & 16 & 32 & 64 & 128 & 256 & 512 & 1024 & 2048 \\
\hline & 4 & $+\mathrm{ve}$ & $+\mathrm{ve}$ & $+\mathrm{ve}$ & $+\mathrm{ve}$ & $+\mathrm{ve}$ & $+\mathrm{ve}$ & $-\mathrm{ve}$ & -ve & -ve & -ve \\
\hline & 8 & $+\mathrm{ve}$ & $+\mathrm{ve}$ & $+\mathrm{ve}$ & $+\mathrm{ve}$ & $+\mathrm{ve}$ & + ve & -ve & -ve & -ve & -ve \\
\hline & 16 & $+\mathrm{ve}$ & $+\mathrm{ve}$ & $+\mathrm{ve}$ & $+\mathrm{ve}$ & - ve & -ve & -ve & -ve & -ve & -ve \\
\hline & 32 & $+\mathrm{ve}$ & $+\mathrm{ve}$ & $+\mathrm{ve}$ & $+\mathrm{ve}$ & $-\mathrm{ve}$ & -ve & -ve & -ve & -ve & -ve \\
\hline 폴 & 64 & $+\mathrm{ve}$ & $+\mathrm{ve}$ & $+\mathrm{ve}$ & $+\mathrm{ve}$ & -ve & -ve & -ve & -ve & -ve & -ve \\
\hline$\Xi$ & 128 & $+\mathrm{ve}$ & $+\mathrm{ve}$ & $+\mathrm{ve}$ & $+\mathrm{ve}$ & -ve & -ve & -ve & -ve & -ve & -ve \\
\hline క & 256 & $+\mathrm{ve}$ & $+\mathrm{ve}$ & $+\mathrm{ve}$ & $+\mathrm{ve}$ & -ve & -ve & -ve & -ve & -ve & -ve \\
\hline$\Xi$ & 512 & $+\mathrm{ve}$ & $+v e$ & $+\mathrm{ve}$ & $+\mathrm{ve}$ & -ve & -ve & -ve & -ve & -ve & -ve \\
\hline जे & 1024 & $+\mathrm{ve}$ & $+\mathrm{ve}$ & $+\mathrm{ve}$ & $+\mathrm{ve}$ & -ve & -ve & -ve & -ve & -ve & -ve \\
\hline & 2048 & $+\mathrm{ve}$ & $+\mathrm{ve}$ & $+\mathrm{ve}$ & $+\mathrm{ve}$ & -ve & -ve & -ve & -ve & -ve & -ve \\
\hline
\end{tabular}

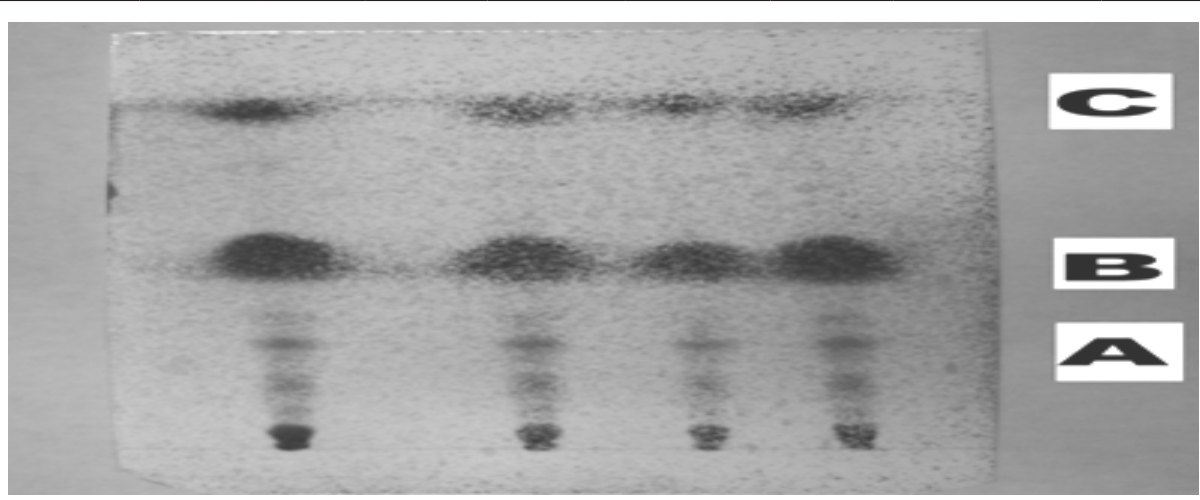

Photo 1. Thin layer chromatogram of diethyl ether clove extract.

TABLE 6. The antimicrobial activity and Rf of diethyl ether extract of clove separated components.

\begin{tabular}{lccc}
\hline Tested compounds & Inhibition zone diameter $(\mathbf{m m})$ & Spots color & \multicolumn{1}{c}{ Rf value } \\
\hline Crude extract & 27 & Pale violet & \\
A & 11.6 & Brown & 0.160 \\
B & 19.0 & 0.546 \\
C & & Dark violet \\
\hline
\end{tabular}




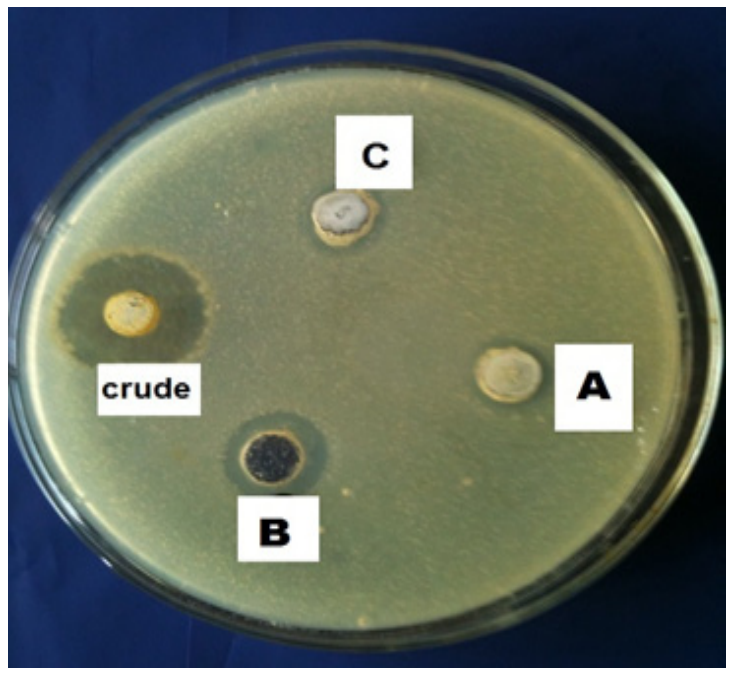

Photo 2. Antimicrobial bioassay of crude clove extract and its separated components against Staphylococcus aureus.

The IR spectrum of compounds A (Table 7 and Fig. 2), B (Table 8 and Fig. 3) and C (Table 9 and Fig. 4) illustrating the presence of main prominent peaks, which indicating the presence of different functional groups.

The gas chromatography mass spectroscopy (GC/MS) of clove diethyl ether extract showed the presence of two major peaks (Fig. 5) such peak denotes specific bioactive compound. Comparing the peak appearance and retention time with the standard library data, the compounds were identified as eugenol (59.7\%) with matching quality $96 \%$, and eugenol acetate $(34.5 \%)$ with matching quality 97\% (Fig. 6 and 7). The GC/MS showed the presence of six minor peaks which represent less than $6 \%$ of total compounds in the clove diethyl ether extract.

In recent times, resistance to anticancer drug has been noticed therefore more study is required to discover the anticancer possibility of medicinal plant resulting substances. Natural and some synthetic compounds can avoid, or inhibit the progression of cancer. In the present study, the anticancer potentiality of crude clove extract was assessed against two types of cancer (colon, HCT 116 tumor and breast MCF 7 tumor). The SRB test is sensitive and more rapid method. It depends on the uptake of the pink aminoxanthine dye (negatively charged), sulphorhodamine B (SRB) by basic amino acids in the cells. The larger the number of cells, the greater amount of dye is taken up and, after fixation, when the cells are disintegrated; the librated dye will give a more intensive color and greater absorbance (Houghton et al., 2007). Color intensity was measured in an ELISA reader and the inhibitory concentration required for $50 \%$ cytotoxicity $\left(\mathrm{IC}_{50}\right)$ for the extract against the two types of cancer, was calculated (Table 10). The results indicated that the extract is potentially cytotoxic to the breast and cancer cell line with a dose dependant response (Table 11). For colon cancer, growth inhibition percentage reached its maximum value $(86.4 \%)$ at $125 \mu \mathrm{g} /$ $\mathrm{ml}$, while, for breast cancer, growth inhibition percentage was $84.2 \%$ at $50 \mu \mathrm{g} / \mathrm{ml}$, Doxorubicinb was used as a positive control.

TABLE 7. The characteristic bands of IR spectrum of compound A separated from clove diethyl ether extract.

\begin{tabular}{lcc}
\hline Peak number & Position & Represented group \\
\hline 1 & 3428 & $\mathrm{O}-\mathrm{H}$ \\
2 & 2970 & $\mathrm{C}-\mathrm{H}$ \\
6 & 1637 & $\mathrm{C}=\mathrm{O}$ \\
7 & 1454 & $\mathrm{C}=\mathrm{C}$ \\
\hline
\end{tabular}




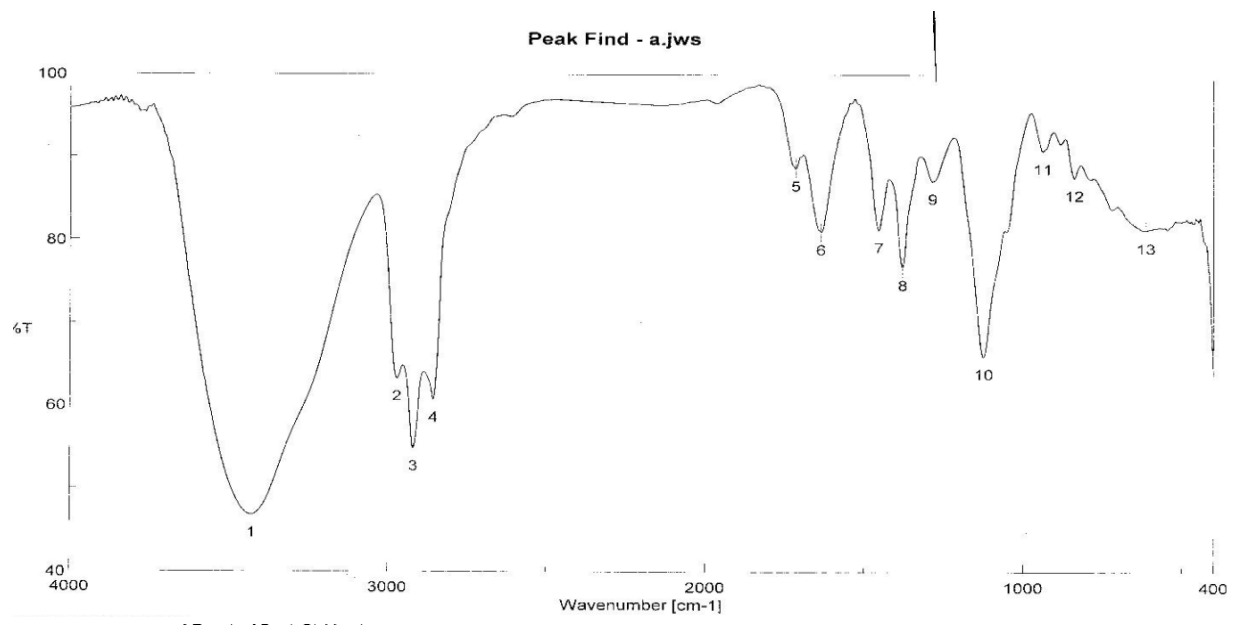

[Result of Peak Picking]

No. Position Intensity No. Position Intensity No. Position Intensity No. Position Intensity

$\begin{array}{llllllllllll}1 & 3428.81 & 46.7801 & 2 & 2970.8 & 63.2981 & 3 & 2920.66 & 54.8155 & 4 & 2857.02 & 60.7076\end{array}$

$\begin{array}{llllllllllll}5 & 1717.3 & 88.5872 & 6 & 1637.27 & 80.9578 & 7 & 1454.06 & 81.2025 & 8 & 1379.82 & 76.7355\end{array}$

$\begin{array}{llllllllllll}9 & 1285.32 & 87.046 & 10 & 11243 & 65.9673 & 11 & 939.163 & 90.6881 & 12 & 839.847 & 87.4706\end{array}$

$13 \quad 614.217 \quad 81.1435$

Fig. 2. IR spectrum of compound A separated from clove diethyl ether extract.

TABLE 8. The characteristic bands of IR spectrum of compound B separated from clove diethyl ether extract.

\begin{tabular}{lcc}
\hline Peak number & Position & Represented group \\
\hline 2 & 3423 & $\mathrm{O}-\mathrm{H}$ \\
3 & 2920 & $\mathrm{C}-\mathrm{H}$ \\
6 & 1646 & $\mathrm{C}=\mathrm{O}$ \\
7 & 1455 & $\mathrm{C}=\mathrm{C}$ \\
13 & 884 & $\mathrm{C}=\mathrm{C}$ aromatic \\
\hline
\end{tabular}

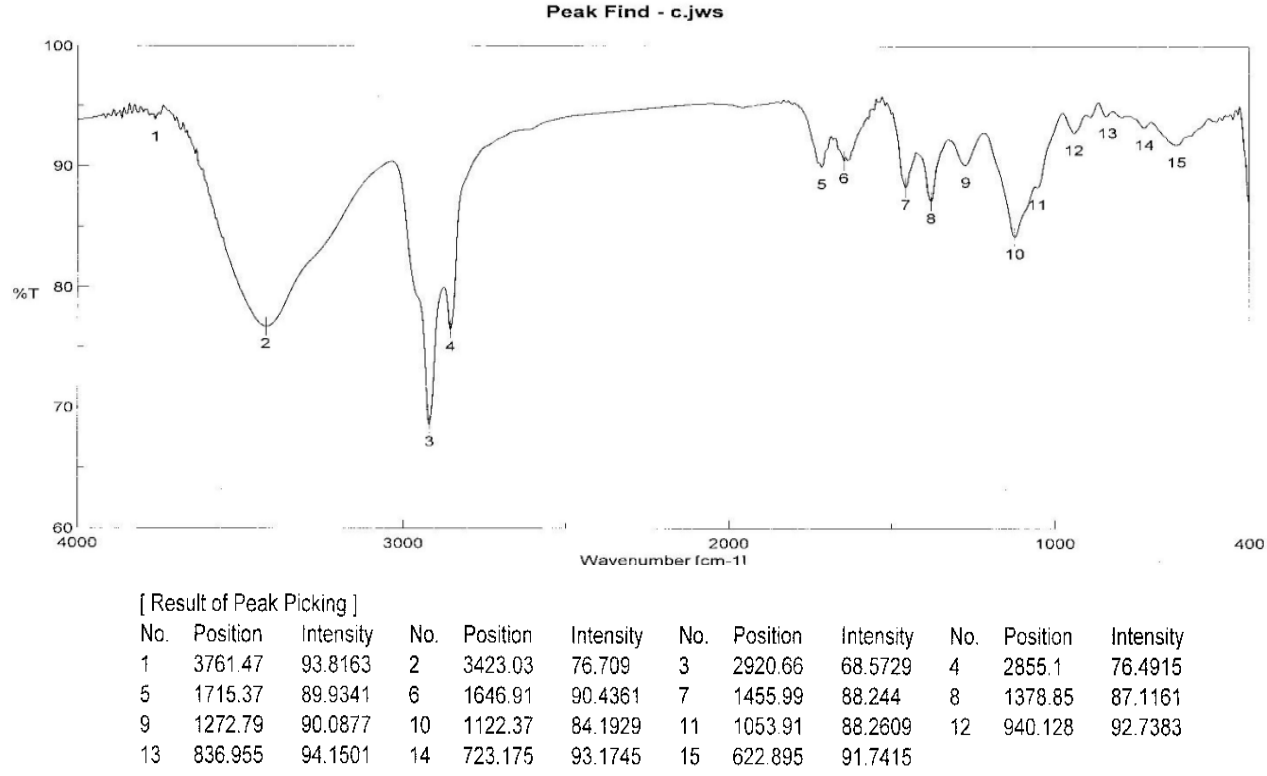

Fig. 3. IR spectrum of compound B separated from clove diethyl ether extract. 
TABLE 9. The characteristic bands of IR spectrum of compound C separated from clove diethyl ether extract

\begin{tabular}{lcc}
\hline Peak number & Position & Represented group \\
\hline 1 & 3423 & O-H \\
2 & 2920 & $\mathrm{C}-\mathrm{H}$ \\
4 & 1692 & $\mathrm{C}=\mathrm{O}$ \\
6 & 1456 & $\mathrm{C}=\mathrm{C}$ \\
13 & 884 & $\mathrm{C}=\mathrm{C}$ aromatic \\
\hline
\end{tabular}

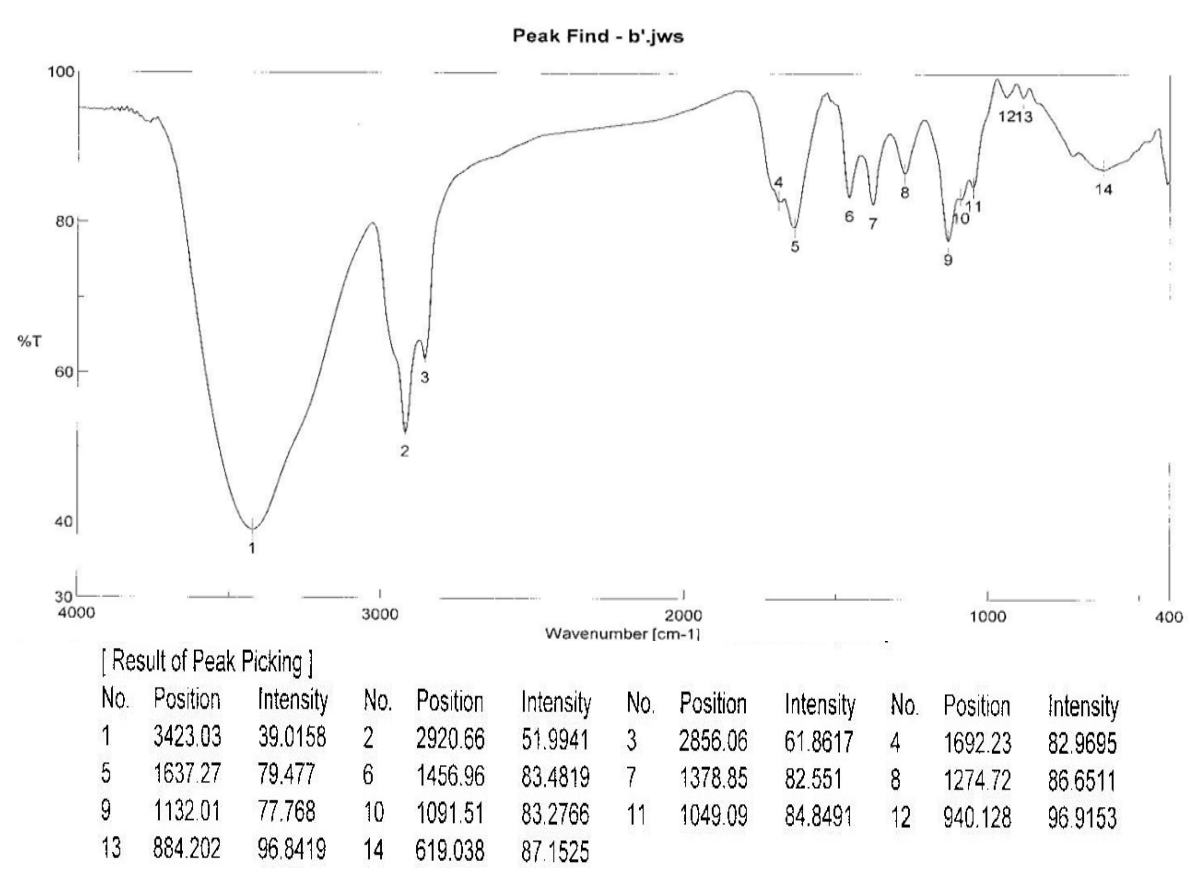

Fig. 4. IR spectrum of compound $C$ separated from clove diethyl ether extract.

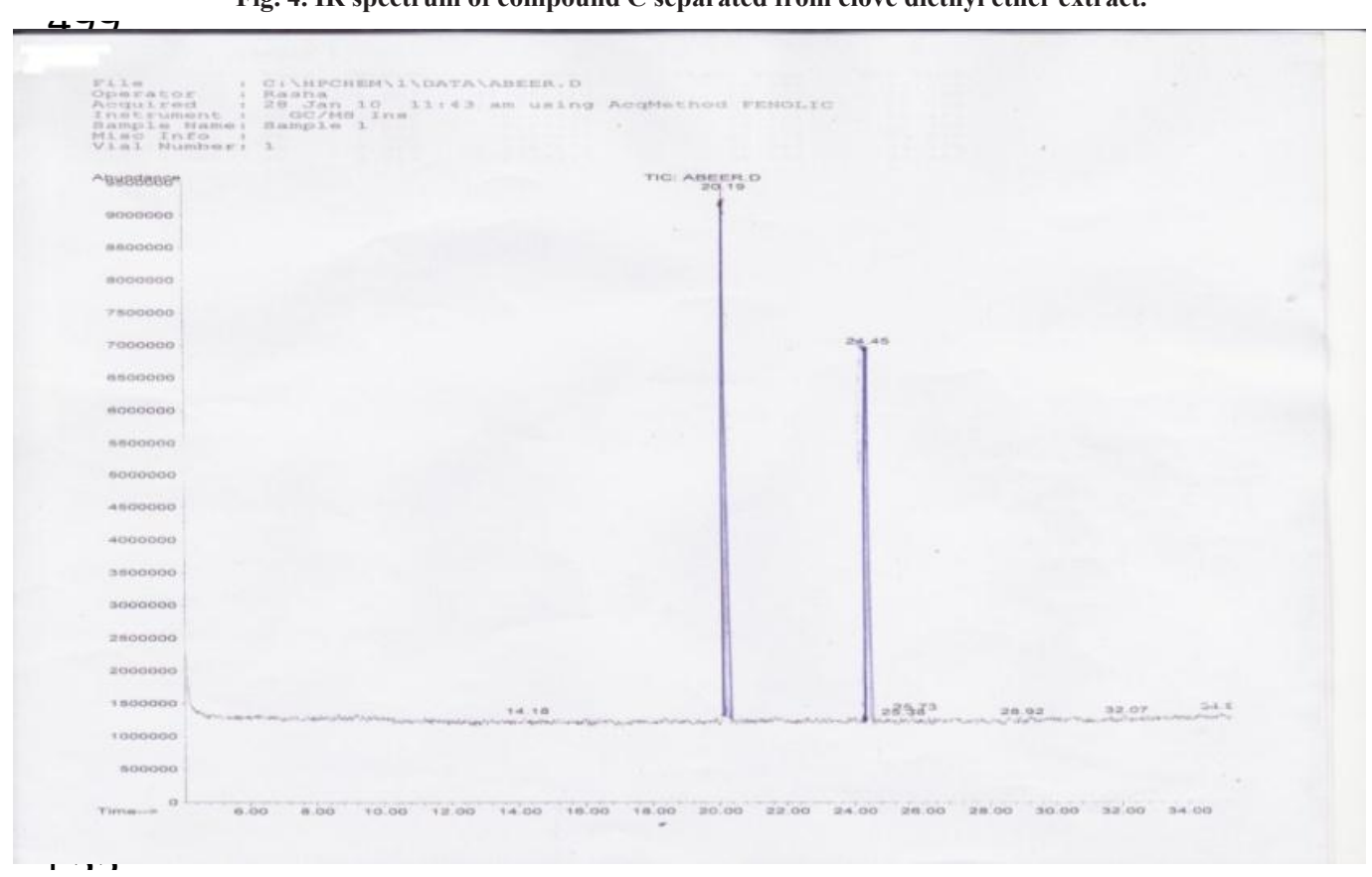

Fig. 5. GC/MS analysis of clove extract.

Egypt. J. Micro. 53 (2018) 


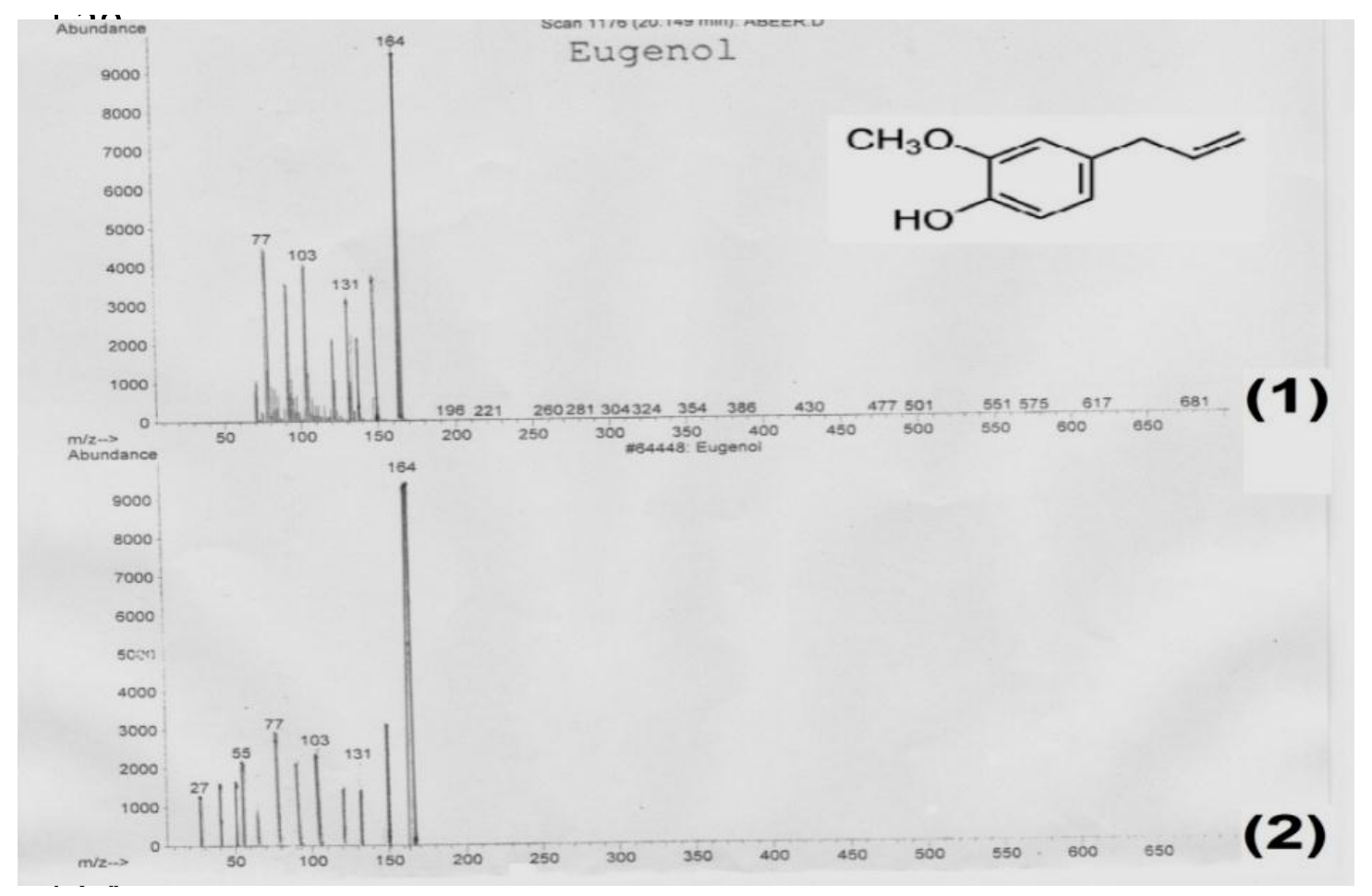

Fig. 6. Mass fragmentation pattern of: (1) Compound B separated from clove diethyl ether extract and (2) Eugenol from the GC/ MS library.

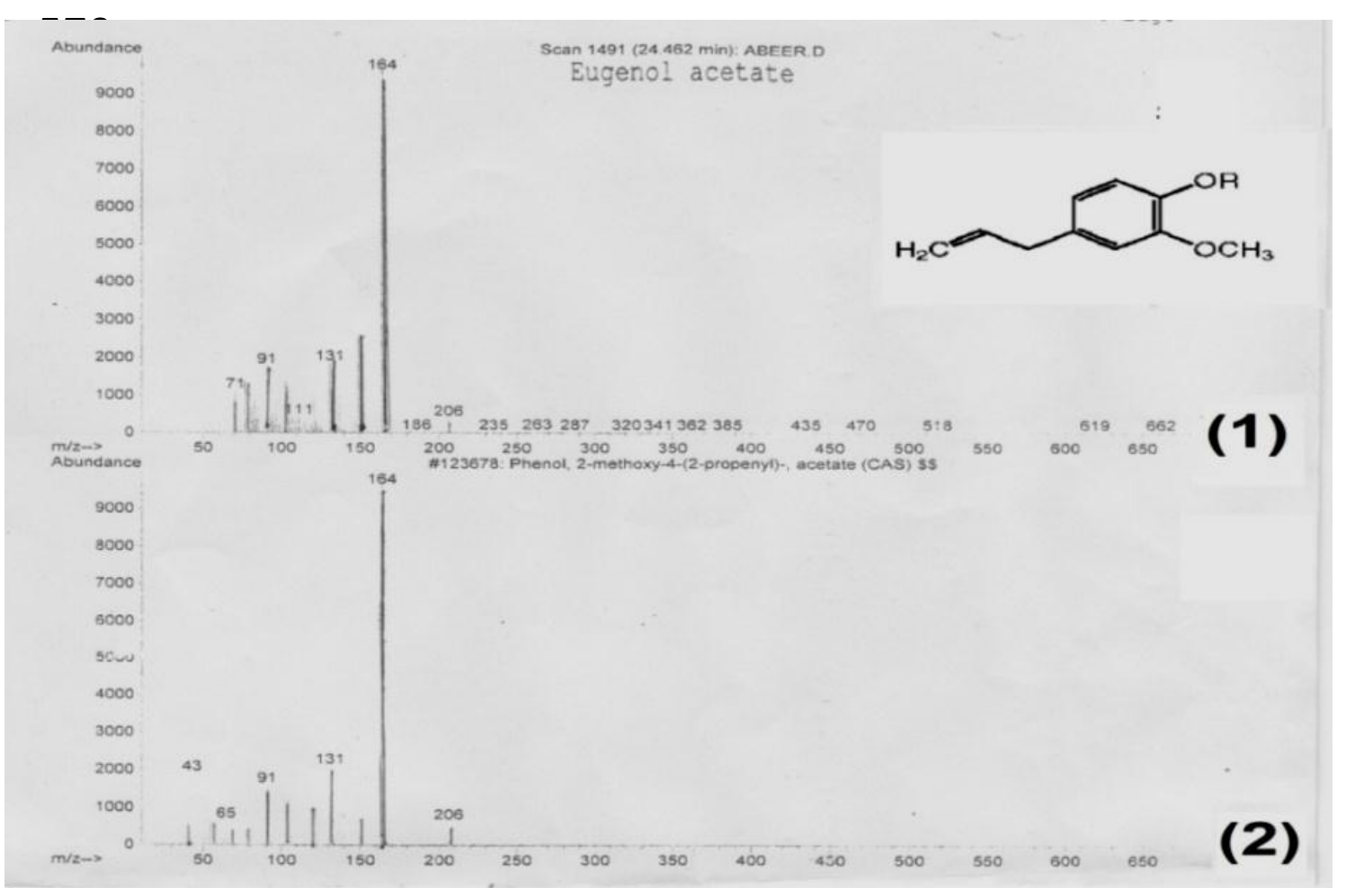

Fig. 7. Mass fragmentation pattern of: (1) Compound C separated from clove diethyl ether extract and (2) Eugenol acetate from the GC/MS library. 
TABLE 10. Potential cytotoxicity and $\mathrm{IC}_{50}$ of Syzygium aromaticum extract on breast cancer (MCF-7) cell line by SRB assay.

\begin{tabular}{|c|c|c|c|}
\hline \multirow{2}{*}{ Tumor cell line } & \multirow{2}{*}{ Compound Conc $\mu \mathrm{g} / \mathrm{m}$} & \multicolumn{2}{|c|}{ Surviving fraction } \\
\hline & & S. aromaticum extract & Doxorubicinb \\
\hline \multirow{5}{*}{$\begin{array}{l}\text { Breast cancer } \\
(\mathrm{MCF}-7)\end{array}$} & 0 & 1 & 1 \\
\hline & 50 & 0.189779 & 0.194273 \\
\hline & 125 & 0.136507 & 0.171715 \\
\hline & 250 & 0.235292 & 0.185526 \\
\hline & 500 & 0.242118 & 0.201330 \\
\hline $\mathrm{IC}_{50} \mu \mathrm{glml}$ & & 26.5 & 29.7 \\
\hline
\end{tabular}

TABLE 11. Potential cytotoxicity and $\mathrm{IC}_{50}$ of Syzygium aromaticum extract on colon cancer (HCT-116) cell line by SRB assay.

\begin{tabular}{|c|c|c|c|}
\hline \multirow{2}{*}{ Tumor cell line } & \multirow{2}{*}{$\begin{array}{c}\text { Compound Conc. } \\
\mu \mathrm{g} / \mathrm{m}\end{array}$} & \multicolumn{2}{|c|}{ Surviving fraction } \\
\hline & & Syzygium aromaticum extract & Doxorubicinb \\
\hline \multirow{5}{*}{$\begin{array}{l}\text { Colon cancer } \\
\text { (HCT-116) }\end{array}$} & 0 & 1 & 1 \\
\hline & 50 & 0.158940 & 0.353846 \\
\hline & 125 & 0.163355 & 0.278060 \\
\hline & 250 & 0.235430 & 0.244162 \\
\hline & 500 & 0.249153 & 0.277778 \\
\hline $\mathrm{IC}_{50} \mu \mathrm{glml}$ & & 27 & 37.3 \\
\hline
\end{tabular}

\section{Discussion}

Many studies all over the world have been showed that medicinal plants and their extract have multi-antimicrobial properties (BocanegraGarcia et al., 2009; Al-Juraifani, 2011 and Bakht, 2011). Results of this study demonstrated clear differences in the antimicrobial effect by the different tested solvents for clove extract, which revealed that each extract showed a distinctive permutation of target organisms suggesting the presence of different bioactive phytochemicals (Ananil et al., 2000). This observation can be justified in terms of the polarity of the compounds being extracted by each solvent (Parekh et al., 2005). In accordance, Kalyoncu et al. (2009) and Keskin et al. (2010) confirmed that plants differ significantly in their activity against tested microorganisms using different solvents. Sharma et al.(2011) demonstrated that ethanolic extracts were found to be more effective than aqueous extracts which support the current results. In most cases, the organic extracts showed the same or greater activity than the aqueous extracts this may be due to that the most of the bioactive compounds from plant origin are generally soluble in polar solvents (Houghton \& Raman, 1998). Parekh et al. (2005) and Majhenic et al. (2007) confirmed that water is not an appropriate solvent to be used for extraction the antibacterial compounds from medicinal plants compared to other solvents. Clove extracts are reported to demonstrate noticeably high free radical scavenging and peroxide inhibition activity indicating its reducing character, which may somewhat explain the inhibition of bacterial growth (Ramadan et al., 2013). Gibreil et al. (2017) studied the antibacterial activity of clove essential oil against five strains of pathogenic bacteria, they illustrated that it could be used as additive constituent in the food and/or pharmaceutical industries field. Tajkarimi et al. 
(2010) explained that the plant substances can affect microbial cells by different antimicrobial mechanisms, including attacking the phospholipid bilayer of cell membrane, disturbing enzyme systems or compromising the genetic material of bacteria. Dua et al. (2014) confirmed that increased libration of intracellular nucleotides and proteinaceous materials from the bacterial cells in the presence of methanol clove extract containing polyphenols indicates that the most important mode of action is membrane damage, which leads to cell death. They illustrated that the destructive effect of clove extract on the cell membrane integrity was illustrated as increase in absorbance at 260 and $280 \mathrm{~nm}$ after incubation of the cells with the extract.

The MIC values of the studied extract were promising against all tested stains, it was found to be efficient against Gram +ve, Gram -ve bacteria, fungi and yeast at lower concentrations. Karou et al. (2005) and Joseph \& Sujatha (2011) illustrated that the great variation in MIC values, suggesting a selective activity of the extract which is in good accordance with the data obtained.

Antibiotic resistant strains possess genes encoding for antibiotic resistance, since plants produce a diversity of compounds with antimicrobial properties, it is expected that plant compounds showing target sites other than those currently used by antibiotics and will be active against drug resistant microbial pathogens (Duarte et al., 2005). Adwan \& Mhanna (2008) suggested that additional effect of phytochemical combined with antibiotic may occur due to a dual attack of both agents at various target sites of the cell. The studied interaction between the tested clove extract and ciprofloxacine showed synergistic effect in agreement with Elbashiti et al. (2011) which demonstrated that some of the tested plant extracts showed synergistic activity when combined with antibiotics against E. coli and Staphyloccocus aureus. Actually, the extracts enclose mixtures of different bioactive compounds; make microbial adaptability very complicated comparing to single-constituent antibiotics (Hemaiswarya et al., 2008). Furthermore, $\mathrm{Xu}$ et al. (2008) suggested that the synergistic effect of any extract may be attributed to the ability of its active component to disturb the cell wall of the cell and depolarize the cytoplasmic membrane and then facilitate the influx of antibiotics inside bacterial cell. Another suggested explanation given by Chanda \& Rakholiya (2011) that the synergistic effect may be due to specific complex formation which becomes more efficient in the inhibition of a given species of microorganisms either by inhibiting the cell wall synthesis or by causing its lysis and death. Sometimes the use of single antibiotic does not produce the required effective inhibitory effects and to overcome this, a combination of drugs often exercises their synergistic effect which exceeds their individual performance Chanda \& Rakholiya (2011).

The TLC analysis of the studied clove diethyl ether extract showed the presence of three distinct spots (compounds), which exhibited some degree of antimicrobial activity, but with lesser degree as compared to the total crude extract. Since it was predicted that the isolated compounds would demonstrate higher antibacterial activity than the crude extract, as it would present in greater concentration, however this is not the case for diethyl ether extract studied against $S$. aureus. It may be explained that the mechanism of many phyto-extract is still unknown and there are many cases where total herb extracts exhibited a better effect than an equivalent dose of an isolated compounds (Williamson, 2001). In good accordance with the study of Horiuchi et al. (2007) who found that the crude extract of Salvia officinalis lower the MICs of resistant Enterococcus while the effective compounds from extract demonstrated low antibacterial activity. Kamatou et al. (2007) suggested further explanation that, since the three compounds were isolated it is probable that they may act synergistically to give the overall antibacterial activities achieved with the crude extract.

GC/MS analysis indicated that clove extract main compounds were eugenol $(59.7 \%)$ and eugenol acetate $(34.5 \%)$. This finding agreed with that reported by Basmacioglu-Malayoglu et al. (2011) who demonstrated nine constituents by GC/MS analysis of clove bud, eugenol $(77.8 \%)$ was the major compound followed by eugenol acetate $(11.74 \%)$. Jian-Guo $\mathrm{Xu}$ et al. (2016) also confirmed that eugenol was found to be the main component (76.23\%) of the essential oil of clove buds followed by b-caryophyllene $(11.54 \%)$, caryophyllene oxide $(4.29 \%)$, and eugenyl acetate $(1.76 \%)$. The mechanisms by 
which microorganisms are inhibited by clove extract and their chemical compounds seem to comprise different mechanisms, Proestos et al. (2006) demonstrated that the phenolic portion of plant extracts has been related to their antioxidant ability and antimicrobial activity. Antioxidants containing a phenolic group play a vital role in avoiding many lifestyle related diseases and aging, being closely associated to the formation of reactive oxygen species (ROS) and to lipid peroxidation. Antioxidants are known for their potential in supporting health and lowering the possibility for cancer, hypertension and heart disease (Wolfe et al., 2003 and Valko et al., 2007). Sema et al. (2007) and Ayoola et al. (2008) illustrated that antibacterial effect of clove may be explained by the action of the phenolic compound eugenol, which was earlier explained by Mason \& Wasserman (1987) that the site and the number of hydroxyl groups on the phenol are considered to be linked to their relative toxicity to microorganisms, with confirmation that increased hydroxylation results in increased toxicity. This phenolic compound can alter proteins and reacts with phospholipids bilayer of cell membrane and changing their permeability (Wenqiang et al., 2007). Phenolics, in the plant extracts with more than one hydroxyl group have metal ion chelating property which may also be effective causal to the antimicrobial properties by leading to the shortage of fundamental metal ions in the growth medium (Ramadan et al., 2013).

Data obtained from IR study of the investigated clove extract indicated the presence of $-\mathrm{OH}$ group, which might be the reason for its inhibitory action. This was supported by Aziz et al. (1998) who demonstrated that the mode of action of $-\mathrm{OH}$ group can easily form hydrogen bonds with active sites of enzymes preventing its action. Abdelfadel et al. (2016) are in agreement with those of Abo El-Maati et al. (2012) who found that, clove extracts exhibited strong antioxidant capacity. FT-IR analysis of clove alcoholic extract studied by Khalid et al. (2016) showed that there is a clear and high intensive band which represents $\mathrm{OH}$ groups as well as moderate band that represents frequency asymmetrical patterns of group $\mathrm{CH}_{2}$ and $\mathrm{CH}_{3}$ of alcoholic compound which are going on with results of this study. They demonstrated another band represented frequency patterns of ester group $\mathrm{C}-\mathrm{O}$ or aromic ketone group $\mathrm{C}=\mathrm{O}$ which combine with more than ring. They estimated that the extract showed highly effect on bacterial growth because the presence of active groups of quinone in the extract that play important role in the inhibition process, which is in consistent with the antimicrobial data obtained for the studied extract.

currently it is well known that natural products and several micronutrients in fruits and vegetables not only show protection against oxidative reaction but also inhibit propagation of cancer cells in culture as well as in vivo (Siriwardhana et al., 2003; Kuete et al., 2009 and Choi et al., 2012). The Active components of phytochemicals that most often seem to be protective against cancer are obtained from plants and assumed to inhibit the inflammatory process that lead to transformation, hyper increase and initiation of carcinogenesis (Aggarwal \& Shishodia, 2006). In the tested two cancer cell lines, the extract showed different patterns of cell growth inhibition activity with dose dependant response. The extract has maximum up to $86.4 \%$ cell death at $125 \mu \mathrm{g} / \mathrm{ml}$ dose with $\mathrm{IC}_{50}$ value of $27 \mu \mathrm{g} / \mathrm{ml}$ for colon cancer while for breast cancer; the growth inhibition percentage was $84.2 \%$ at $50 \mu \mathrm{g} / \mathrm{ml}$ dose with $\mathrm{IC}_{50} 26.5 \mu \mathrm{g} /$ $\mathrm{ml}$. Curing cells with a cytotoxic compound can result in a variety of cell death. The cells may suffer necrosis (lose membrane integrity and die quickly as a result of cell lysis). The cells can prevent actively growing and dividing (a decrease in cell viability), or the cells can stimulate a genetic plan of controlled cell death (apoptosis). Apoptosis is a significant phenomenon in cancer chemotherapy, because anticancer drugs apply their antitumor effect against cancer cells by stimulating apoptosis (Salomons et al., 1999). Therefore, it is assumed that eugenol may exert its cytotoxic activity on various cancer cells encourage apoptosis. In consistent, Parashar et al. (2006) reported that clove oil and eugenol have considerable cytotoxic effect against human fibroblasts and endothelial cells. Similarly, it has been shown by Vinay et al (2011) that clove has several capacities to cause cell death in the different cancerous cell lines of human origin and that the eugenol present in clove oil extract is an efficient cytotoxic cause for different type of cancer cells and it is endowed with apoptotic inducing capability. It was reported by ElAwady et al (2015) that medicinal plants may help host resistance against infection by re- 
stabilizing body equilibrium and conditioning the body tissues. Many studies report that the process of cancer progress is due to genetic and epigenetic changes which lead to disturbance in basic biological functions, such as cell division, differentiation, angiogenesis (Sartor \& Pal, 2013 and Higano et al., 2014).

\section{Conclusion}

The in vitro results of the present investigation give evidence that the compounds extracted from clove by diethyl ether have powerful activity of multi-antimicrobial properties especially to pathogenic strains. Since clove displayed a decisive antimicrobial activity, it can be considered viable alternative to conventional antifungal, antibacterial and anticarcinogenic agent with relatively minimal side effect, lesser toxicity and lower cost. Synergistic activity of the extract and ciprofloxacin could provides different manner to overcome a problem of bacterial infections caused by MDR S. aureus and can be translated into useful clinical applications in order to raise the pharmacological activity or decrease the resistance behavior of resistant $S$. aureus. There are many proofs indicating that medicinal plants will constitute a prevalent alternative for cancer protection and effective treatment of bacterial diseases as an alternative to the costly antibiotics.

\section{$\underline{\text { References }}$}

Ababutain, I.M. (2011) Antimicrobial activity of ethanolic extracts from some medicinal plant. Australian J.of Basic and Applied Sciences, 5(11), 678-683.

Abdelfadel, M.M., Khalaf, H.H., Sharoba, A.M. and Assous, M.T.M. (2016) Effect of extraction methods on antioxidant and antimicrobial activities of some spices and herbs extracts. J. Food Technol. Nutr. Sci. 1(1), 1-14

Abo El-Maati, M.F., Labib, S.M., Al-Gaby, A.M.A. and Ramadan, M.F. (2012) Antioxidant properties of different extracts from five medicinal plants. Zagazig J. of Agricultural Res. 39(4), 1-13.

Adwan, G. and Mhanna, M. (2008) Synergistic effects of plant extracts and antibiotics on Staphylococcus aureus strains isolated from clinical specimens. Middle East J. Sci. Res. 3(3), 134-139.
Aggarwal, B.B. and Shishodia, S. (2006) Molecular targets of dietary agents for prevention and therapy of cancer. Biochem Pharmacol. 71, 1397-421.https:// doi.org/10.1016/j.bcp.2006.02.009.

Al-Juraifani, A.A. (2011) Antimicrobial activity of some medicinal plants used in Saudi Arabia. Canadian J. of Pure \& Applied Sciences, 5(2), 1509-1512.

Ananil, K., Hudson, J.B., De Souzal, C., Akpaganal, K., Tower, G.H.N, Amason, J.T. and Gbeassor, M. (2000) Investigation of medicinal plants of Togo for antiviral and antimicrobial activities. Pharmaceutical Biol. 38(1), 40-45. https://doi.org/10.1076/13880209(200001)3811-bft040.

Atlas, R.M. (1993) "Handbook of Microbiology Media" Laurence, C. and Parks, L.C. (Ed.), pp. 278, 538, 785. Parks, CRC press.

Atteiaa, H.G. and Husseinb, E.M. (2014) In vitro antibacterial and synergistic effects of some plant extracts against Staphylococcus aureus and Klebsiella pneumonia J. Antimicrob. 129, 338-346.

Ayoola, G.A., Lawore, F.M., Adelowotan, T., Aibinu, I. E., Adenipekun, E., Coker, H.A.B. and Odugbemi, T.O. (2008) Chemical analysis and antimicrobial activity of the essential oil of Syzygium aromaticum (Clove). Afr. J. Microbiol. Res. 2, 162-166.

Aziz, N., Farag, S., Mousa, L. and Abo-Zaid, M. (1998) Comparative antibacterial and antifungal effects of some phenolic compounds. Microbios, 93(374), 43-54.

Bakht, J., Tayyab, M., Ali, H., Islam, A. and Shafi, M. (2011) Effect of different solvent extracted sample of Allium sativum (Linn) on bacteria and fungi. African J. of Biotechnology, 10(31), 5910-5915.

Basmacioglu-Malayoglu, H., Ozdemir, P. and Hames-Kocabas, E.E. (2011) Chemical compositions and antibacterial activity of the essential oils from some plant species. EgeUniversitesiZiraatFakultesiDergisi, $\quad \mathbf{4 8 ( 1 )}$, 11-18.

Bassam, A.S., Ghaleb, A., Dahood, A.S., Naser, J. and Adwan, K. (2004) Antibacterial activities of some plant extracts utilized in popular medicine in palestine. Turk. J. Biol. 28, 99-102.

Bocanegra-Garcia, V., Camacho-Corona, M., Ramirez- 
Cabrera, M., Rivera, G. and Garza-Gonzatez, G.R. (2009) The bioactivity of plant extracts against representative bacterial pathogens of the lower respiratory tract. BMC Research Notes, 2, 95.https:// doi.org/10.1186/1756-0500-2-95.

Chaieb, K., Zmantar, T., Ksouri, R., Hajlaoui, H., Mahdouani, K., Abdelly, C. and Bakhrouf, A. (2007) Antioxidant properties of the essential oil of Eugenia caryophyllata and its antifungal activity against a large number of clinical Candida species. Mycoses, 50(5), 403-406. https://doi.org/10.1111/ j.1439-0507.2007.01391.x.

Chanda, S. and Rakholiya, K. ( 2011) Combination therapy: Synergism between natural plant extracts and antibiotics against infectious diseases. Microbiol. Book Series, 520-529.

Choi, S., Hyun, J.J., Young, C., Mi, S.K., Yu, R.L., Ha, S.K., Shin, W.C., Byeong, H.J., Sun, I.W., Tae, W.K. and Jong, W.C. (2012) Antioxidant and anticancer activity of fractions of the ethanol extract of Naematoloma sublateritium. J. of Medicinal Plants Research, 6(7), 1344-1352.

CLSI (2005) Clinical and Laboratory Standards Institute,. Performance standards for antimicrobial susceptibility testing. CLSI document M100-S15. Wayne.

Deshpande, A.R., Musaddiq, M. and Bhandange, D.C. (2004) Studies on antibacterial activity of some plant extracts. J. of Microbial. World, 6(1), 45-49.

Dionisi, H.M., Lozada, M. and Olivera, N.L. (2012) Bioprospection of marine microorganisms: Biotechnological applications and methods. Rev. Argent. Microbiol. 44(1), 49-60. https://doi. org/10.1590/S0325-75412012000100010.

Dua, A., Garg, G., Nagar, S. and Mahajan, R. (2014) Methanol extract of clove (Syzygium aromaticum Linn.) damages cells and inhibits growth of enteropathogens. Journal of Innovative Biology, 1(4), 200-205.

Duarte, M.C., Figueira, G.M., Sartoratto, A., Rehder, V.L. and Delarmelina, C. (2005) AntiCandida activity of Brazilian medicinal plants. J. Ethnopharmacol.97(2), 305-11. https://doi. org/10.1016/j.jep.2004.11.016.

El-Awady, M.A., Awad, N.S. and El-Tarras, A.E.
(2015) Evaluation of the anticancer activities of pomegranate (Punica granatum) and harmal (Rhazya stricta) plants grown in Saudi ArabiaInt. $J$. Curr. Microbiol. App. Sci. 4(5), 1158-1167.

Elbashiti, T.A., Abdelraouf, A.E. and Atef, A.M. (2011)The antibacterial and synergistic effects of some Palestinian plant extracts on Escherichia coli and Staphylococcus aureus. Functional Plant Science and Biochemistry, 5(1), 57-62.

El-Deeb, M.S. (1985) Chromatographic and thermal analysis of certain volatile oil containing drugs. $P h$. $D$ Thesis. Cairo Univ. Fac. Pharm. Cairo, Egypt.

European Committee for Antimicrobial Susceptibility Testing (EUCAST) (2000) The European Society of Clinical Microbiology and Infectious Diseases (ESCMID) Definitive Document EDEF 3.1, June 2000. Determination of minimum inhibitory concentrations (MICs) of antibacterial agents by agar dilution. Clinical Microbiology and Infection, Volume 6 Number 9, September 2000.

Eyambe, G., Canales, L. and Banik, B.K. (2011) Antimicrobial activity of eugenol derivatives. Heterolettr, 1(2), 154-157.

Fleischauer, A.T., Simonsen, N. and Arab, L. (2003) Antioxidant supplements and risk of breast cancer recurrence and breast cancer-related mortality among postmenopausal women, Nutr. Cancer, 46(1), 15-22. https://doi.org10.1207/S15327914NC 4601_02

Gail, L.W., John, A.W., Mandell, D.A. and Bennett, S. (1995) "The Principles and Practice of Infectious Diseases", pp. 19-99. $4^{\text {th }}$ ed. New York: Churchill Livingstone Inc.

Ghaly, F.M., Dina, M.B., Shahira, H.M., Abd EL-Salam, Sohair S., Somayah, M.A. and EL-Makhzangy, Abeer A. (2015) Efficacy of ciprofloxacin and clove extract on bacterial infection of Clarias gariepinus. Middle East J. Appl. Sci. 5(1), 01-09.

Gibreil, A.Y., Abdeldaeim, M.H. and Ali, H.G.M. (2017) Antibacterial activity of clove (Syzigium aromaticum $\mathrm{L}$ ) essential oil and gamma irradiation against some food-borne pathogens in minced chicken meat. Arab J. of Nuclear Science and Applications, 50(1), 179-193.

Han, X. and Parker, T.L. (2017) Anti-inflammatory activity of clove (Eugenia caryophyllata) essential 
oil in human dermal fibroblasts. Pharmaceutical Biology, 55(1), 1619-1622. https://doi.org/10.1080/ 13880209.2017.1314513.

Hemaiswarya, S., Kruthiventi, A.K. and Doble, M. (2008) Synergism between natural products and antibiotics against infectious diseases. Phytomedicine, 15(8), 639-652. https://doi. org/10.1016/j.phymed.2008.06.008.

Higano, C.S., Small, E.J., Schellhammer, P., Yasothan, U., Gubernick, S., Kirkpatrick, P., Kantoff, P.W. and Sipuleucel, T. (2010) Nat Rev Drug Discov. 9(7), 513-514. doi: 10.1038/nrd3220.

Hoffman-Censits, J. and Fu, M. (2013) Chemotherapy and targeted therapies: Are we making progress in castrate-resistant prostate cancer Semin. Oncol. 40, 361-374. https://doi.org/10.1053/j.seminoncol. 2013.04.015.

Horiuchi, K.., Shiota, S., Kuroda, T., Hatano, T., Yoshida, T. and Tsuchiya, T. (2007) Potentiation of antimicrobial activity of aminoglycosides by carnosol from Salvia officinalis. Biol. Pharm. Bull. 30(2), 287-290. https://doi.org/10.1248/bpb. 30.287.

Houghton, P.J. and Raman, A. (1998) "Laboratory Handbook for the Fractionation of Natural Extracts". https://doi.org/10.1007/978-1-4615-5809-5.

Houghton, P., Fang, R., Techatanawat, I., Steventon, G., Hylands, P.J. and Lee, C.C. (2007) The sulphorhodamine (SRB) assay and other approaches to testing plant extracts and derived compounds for activities related to reputed anticancer activity. Methods, 42, 377-387. https://doi.org/10.1016/j. ymeth. 2007.01.003.

Jian-Guo Xu , Ting Liu, Qing-Ping Hu and Xin-Ming Cao (2016) Chemical composition, antibacterial properties and mechanism of action of essential oil from clove buds against Staphylococcus aureus. Molecules, 21(9), 1194. https://doi.org/10.3390/ molecules 21091194.

Jonathan, S.G. and Fasidi, I.O. (2003) Requirements for vegetative growth of Tricholoma lobayensis (Heim), A Nigerian Edible Fungus. Adv. Food Sci. 25(3), 9195.

Joseph, B. and Sujatha, S. (2011) Bioactive compounds and its autochthonous microbial activities of extract and clove Oil (Syzygium aromaticum L.) on some food borne pathogens. Asian J. Biological Sciences, 4(1), 35-43. https://doi.org/10.3923/ajbs.2011.35.43.

Joshi, B., Sah, G.P., Basnet, B.B., Bhatt, M.R., Sharma, D., Subedi, K., Pandey, J. and Malla, R. (2011) Phytochemical extraction and antimicrobial properties of different medicinal plants: Ocimum sanctum (Tulsi), Eugenia caryophyllata (Clove), Achyranthes bidentata (Datiwan) and Azadirachta indica (Neem). J. Microbiol. Antimicrobials, 3(1), 1-7.

Kalyoncu, F., Minareci, E. and Minareci, O. (2009) Antimicrobial activity of five endemic Asperula species from Turkey. Iranian J. Pharmaceutical Res. 8(4), 263-268.

Kamatou, G.P.P., Vuuren, S.F.V., Heerden, F.R.V., Seaman, T. and Viljoen, A.M. (2007) Antibacterial and antimycobacterial activities of South African Salvia species and isolated compounds from $S$. chamelaeagnea. South African J. Botany, 73(4), 552-557. https://doi.org/10.1016/j.sajb.2007.05.001.

Karou, D., Mamoudou, H.D., Jacques, S. and Alfred, S.T. (2005) Antioxidant and antibacterial activities of polyphenols from ethnomedicinal plants of Burkina Faso. African Journal of Biotechnology, 4(8), 823-828.

Keskin, D., Oskay, D. and Oskay, M. (2010) Antimicrobial activity of selected plant spices marketed in the West Anatolia. Int. J. Agric. Biol. 12(6), 916-920.

Khalid abdul Kareem, M., Mustafa Abdulkadhim, H. and Noori, Sawsan (2016) Chemical composition and anti-bacterial effects of clove (Syzygium aromaticum) flowers. Int. J .Curr. Microbiolo. App. Sci. 5(2), 483-489. https://doi.org/10.20546/ ijcmas.2016.502.054 .

Kouidhi, B., Zmantar, T. and Bakhrouf, A. (2010) Anticariogenic and cytotoxic activity of clove essential oil (Eugenia caryophyllata) against a large number of oral pathogens. Ann. Microbiol. 60, 599604. https://doi.org/10.1007/s13213-010-0092-6.

Kuete, V., Vouffo, B., Mbaveng, A.T., Vouffo, E.Y., Siagat, R.M. and Dongo, E. (2009) Evaluation of Antiaris africana methanol extract and compounds for antioxidant and antitumor activities. Pharm. Biol. 47(11), 1042-1049. https://doi. org/10.3109/13880200902988595 
Kumar, P.S., Febriyanti, R.M., Sofyan, F.F., Luftimas, D.E and Abdulah, R. (2014) Anticancer potential of Syzygium aromaticum L. in MCF-7 human breast cancer cell lines. Pharmacogn Res. 6(4), 350-354. https://doi.org/10.4103/0974-8490.138291.

Kumar, U., Brajesh, K., Bhandari, A. and Kumar, Y. (2010) Phytochemical investigation and comparison of antimicrobial screening of clove and cardamom. Int. J. Pharm. Sci. Res. 1(12), 138-147. http://dx.doi. org/10.13040/IJPSR.0975-8232.1(12).138-47.

Louw, C.A., Regnier, T.J. and Korsten, L. (2002) Medicinal bulbous plants of South Africa and their traditional relevance in the control of infectious diseases. J. Ethnopharmacol. 82(2-3), 147-154. https://doi.org/10.1016/S0378-8741(02)00184-8.

Majhenic, L., kerget, M.S. and Knez, Z. (2007) Antioxidant and antimicrobial activity of guarana seed extracts. Food Chemistry, 104(3), 1258-1268. https://doi.org/10.1016/j.foodchem.2007.01.074.

Mandal, S., Manisha, M.D. and Pal, N.K. (2004) Evaluation of combination effect of ciprofloxacin and cefazolin against Salmonella enterica serovar typhi isolates by in vitro methods. Calicut. Med. J. 2(2), e2.

Mason, T. and Wasserman, B. (1987) Inactivation of red beet beta-glucan synthase by native and oxidized phenolic compounds. Phytochemistry, 26, 2197-2202.

Mohammad, F.H. and Al-Kayali, Rawaa S. (2016) Synergistic effect of Thymbra spicata L extracts with antibiotics against multidrug-resistant Staphylococcus aureus and Klebsiella pneumonia strains. Iran J. Basic Med. Sci. 19(11), 1193-1200.

Muhtasib, H.G. (2006) Anticancer and medicinal properties of essential oil and extracts of East Mediterranean sage (Salvia triloba). Advances in Phytomedicine, 2, 169-180. https://doi.org/10.1016/ S1572-557X(05)02010-6.

Mukherjee, P.K. and Wahile, A. (2006) Integrated approaches towards drug development from Ayurveda and other Indian system of medicines. J. Ethnopharmacol. 103, 25-35. https://doi. org/10.1016/j.jep.2005.09.024.

National Committee for Clinical Laboratory Standards (NCCLS) (1994) Methods for dilution antimicrobial susceptibility tests for bacteria that grow aerobically; approved standard- $4^{\text {th }}$ ed. NCCLS document M7 A4. [ISBN 1-56238-309-4] NCCLS, 940 West Valley Road, Suite 1400, Wayne, PA 19087. USA.

National Committee for Clinical Laboratory Standards (NCCLS) (2002) Methods for dilution antimicrobial susceptibility tests of bacteria that grow aerobically. Approved Standard M100-S12. Wayne. PA, NCCLS.

Oulkheir, S., Aghrouch, M., El Mourabit, F., Dalha, F., Graich, H., Amouch, F., Ouzaid, K., Moukale, A. and Chadli, S. (2017) Antibacterial activity of essential oils extracts from Cinnamon, Thyme, Clove and Geranium against a Gram Negative and Gram Positive pathogenic bacteria. J. of Diseases and Medicinal Plants, 3(2-1), 1-5. https://doi.org/10. 11648/j.jdmp.s. 2017030201.11

Parekh, J., Jadeja, D. and Chanda, S. (2005) Efficacy of aqueous and methanol extracts of some medicinal plants for potential antibacterial activity. Turk. J. Bio. 29, 203-210.

Prashar, A. Locke, I.C. and Evans, C.S. (2006) Cytotoxicity of clove (Syzygium aromaticum) oil and its major components to human skin cells. Cell Prolif. 39(4), 241-248. https://doi.org/10.1111/ j.1365-2184.2006.00384.x

Proestos, C., Boziaris, I.S., Nychas, G.J.E. and Komaitis, M. (2006) Analysis of flavonoids and phenolic acids in Greek aromatic plants: Investigation of their antioxidant capacity and antimicrobial activity. Food Chem. 95(4), 664-671. https://doi.org/10.1016/j. foodchem.2005.01.049.

Ramadan, M.F., Asker, M.M.S. and Tadros, M. (2013) Lipid profile, antiradical power and antimicrobial properties of Syzygium aromaticum oil. Grasas $Y$ Aceites, 64(5), 509-520. https://doi.org/10.3989/ gya.011713.

Salomons, G.S., Smets, L.A. and Verwijis-Janssen, M. (1999) Bcl-2 family members in childhood acute lymphoblastic leukemia: Relationships with features at presentation, in vitro and in vivo drug response and long term clinical outcome. Leukemia, 13, 1574-80.

Sartor, O. and Pal, S.K. (2013) Abiraterone and its place in the treatment of metastatic crpc. Nat. Rev. Clin. Oncol. 10, 6-8.

Sema, A., Nursel, D. and Süleyman, A. (2007) 
Antimicrobial activity of some spices used in the meat industry. Bull. Vet. Inst. Pulawy, 51, 53-57.

Shanahan, P.M., Karamat, K.A., Thomson, C.J. and Amyes, S.G. (2000) Characterization of multidrug resistant Salmonella typhi isolated from Pakistan. Epidemiol. Infect. 124(1), 916. https://doi. org/10.1017/s0950268899003453.

Shanmugam, S. and Bhavani, P. (2014) Studies on the comparison of phytochemical constituents and antimicrobial activity of Curcuma longa varieties. Int. J. Curr. Microbiol. App. Sci. 3(9), 573-581.

Sharma, M., Mohan, V., Abraham, M., Joshy, P.J. and Reghuvaran, D.K. (2011) Antimicrobial screening of different extracts of South Indian medicinal plants of meliaceae. J.of Medicinal Plants Res. 5(5), 688-695.

Siriwardhana, N., Lee, K.W., Kim, S.H., Ha, J.W. and Jeon, Y.J. (2003) Antioxidant activity of Hizikia fusiformis on reactive oxygen species scavenging and lipid peroxidation Inhibition. Food Sci. Tech. Int. 9(5), 339-346. https://doi.org/ abs/10.1177/1082013203039014.

Skehan, P., Storeng, R., Scudiero, D., Monks, A., Mcmahon, J., Vistica, D., Warren, J.T., Bokesch, H., Kenney, S. and Boyd, M.R. (1990) New colorimetric cytotoxicity assay for anticancer-drug screening. $J$. Nat. Cancer Inst. 82(13), 1107-1112.

Snedecor, G.W. and Cochran, W.G. (1982) "Statistical methods", 6 $6^{\text {th }}$ ed, pp. 325-330. lowa State Univ. Press, Ames, Iowa, USA.

Sundaram, S., Verma, S.K. and Dwivedi, P. (2011) In vitro cytotoxic activity of Indian medicinal plants used traditionally to treat cancer. Asian Journal of Pharmaceutical and Clinical Research, 4(1), 27-29.

Tajkarimi, M.M., Ibrahima, S.A. and Cliver, D.O. (2010) Antimicrobial herb and spice compounds in food. Food Control, 21, 1199-1218. https://doi. org/10.1016/j.foodcont. 2010.02.003.

Torella, J.P., Chait, R. and Kishony, R. (2010) Optimal drug synergy in antimicrobial treatments. PLOS Comput Biol. 6(6), 1-8. https://doi.org/10.1371/ journal.pcbi.1000796.

Truiti, M. and Sarragiotto, M. (1998) Three 5-methylcoumarins from Chaptalia nutans.
Phytochemistry, 47(1), 97-99. https://doi. org/10.1016/s0031-9422(97)00524-4

Valko, M., Leibfritz, D., Moncola, J., Cronin, M.T. D., Mazura, M. and Telser, J. (2007) Free radicals and antioxidants in normalphysiological functions and human disease. International Journal of Biochemistry and Cell Biology, 39(1), 44-84. https:// doi.org/ 10.1016/j.biocel. 2006.07.001.

Vidaillac, C., Guillon, J., Arpin, C., Forfar-Bares, I., Ba, B.B., Grellet, J., Moreau, S., Caignard, D.H., Jarry, C. and Quentin, C. (2007) Synthesis of omeprazole analogues and evaluation of these as potential inhibitors of the multidrug efflux pump NorA of Staphylococcus aureus. Antimicrob Agents Chemother. 51, 831-838. https://doi.org/10.1128/ AAC.01306-05

Vinay, D., Richa, S., Showket, H., Chaiti, G. and Mausumi, B. (2011) Comparative anticancer potential of clove (Syzygium aromaticum) - an Indian spice - against cancer cell lines of various anatomical origin. Asian Pacific J. of Cancer Prevention, 12(8), 1989-1993.

Wenqiang, G., Shufen, L., Ruixiang, Y., Shaokun, T. and Can, Q. (2007) Comparison of essential oils of clove buds extracted with supercritical carbon dioxide and other three traditional extraction methods. Food Chem. 101(4), 1558-1564. https://doi.org/10.1016/j. foodchem.2006.04.009.

Williamson, E. (2001) Synergy and other interactions in phytomedicines. Phytomedicine, 8(5), 401409. https://doi.org/10.1016/b978-0-7020-29332.00007-1

Wolfe, K., Wu, X. and Liu, R.H. (2003) Antioxidant activity of apple peels. J. of Agricultural and Food Chemistry, 51(3), 609-614. https://doi.org/ 10.1021/ jf020782a.

Xu, J., Zhou, F., Ji, B.P., Pei, R.S. and Xu, N. (2008) The antibacterial mechanism of carvacrol and thymol against Escherichia coli. Lett. Appl. Microbiol. 47(3), 174-179. https://doi.org/10.1111/j.1472765X.2008.02407.x.

(Received 27/ 1/2018; accepted $16 / 5 / 2018$ ) 


\section{فعالية مستخلص الأيثيل إيثر لنبات القرنفل علي نمو بعض الكائنات الممرضه و بمزجها بالمضادات الحيبويه ضد المئل السلاله المقاومه Staphylococcus aureus}

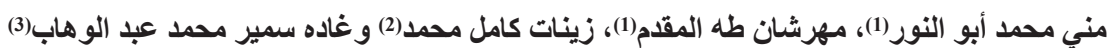

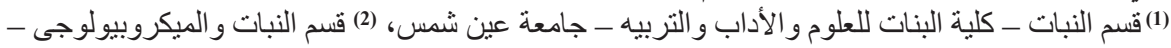

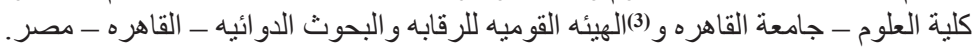

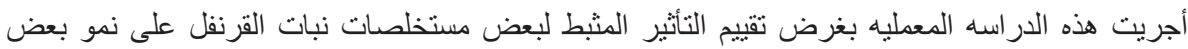

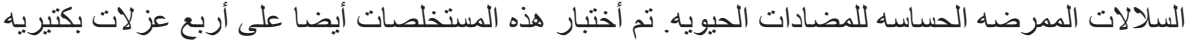

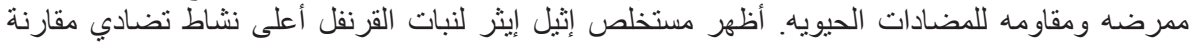

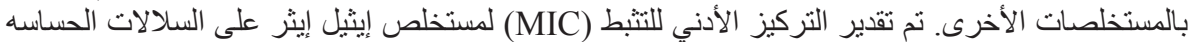

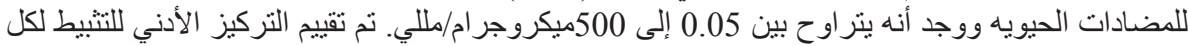

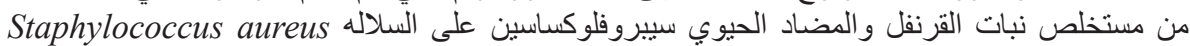

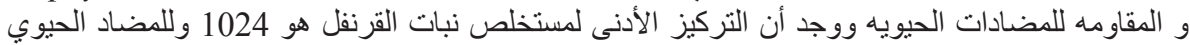

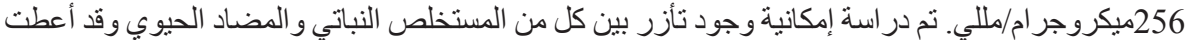

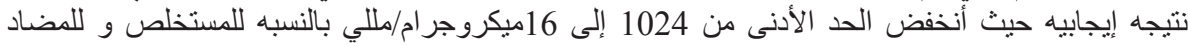

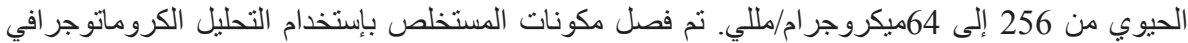

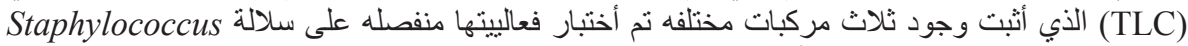

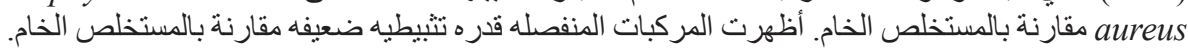

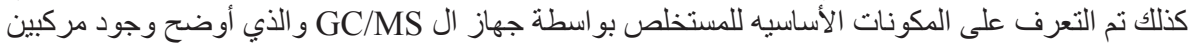

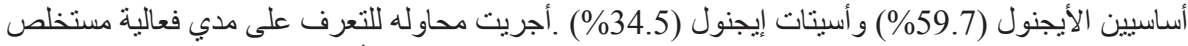

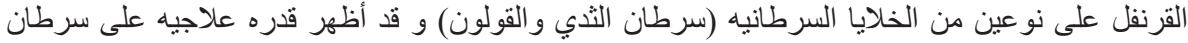
القولون بنسبة86.4\% عند نركيز 125ميكروجر ام/مللي و 84.2\% عند 50ميكرو جر ام/مللي لسرطان الثني. 